\title{
Chapter 15 \\ Impacts of Plant Invasions on Terrestrial Water Flows in South Africa
}

\author{
David C. Le Maitre (D), James N. Blignaut (D), Alistair Clulow (D, \\ Sebinasi Dzikiti D, Colin S. Everson D, André H. M. Görgens, \\ and Mark B. Gush $\mathbb{D}$
}

\begin{abstract}
Considerable advances have been made since the first estimates of the impacts of invasive alien plants on water resources in the early 1990s. A large body of evidence shows that invasive alien plants can increase transpiration and evaporation losses and thus reduce river flows and mean annual runoff. Riparian invasions, and those in areas where groundwater is accessible, have 1.2-2 times the impact of invasions in dryland areas. The magnitude of the impacts is directly related to differences between the invading species and the dominant native species in size, rooting depth and leaf phenology. Information on the impacts has been successfully used to compare the water use of invasive plants and different land cover classes, to quantify the water resource benefits of control measures, and to prioritise areas for control operations. Nationally, the impacts of invasive alien plants on surface water runoff are estimated at $1.44-2.44$ billion $\mathrm{m}^{3}$ per year. The most affected primary catchments ( $>5 \%$ reduction in mean annual runoff) are located in the Western and Eastern Cape, and KwaZulu-Natal. If no remedial action is taken, reductions in surface water runoff could increase to $2.59-3.15$ billion $\mathrm{m}^{3}$ per year, about $50 \%$
\end{abstract}

D. C. Le Maitre $(\bowtie)$

Centre for Invasion Biology, Natural Resources and the Environment, Council for Scientific and Industrial Research, Stellenbosch, South Africa

e-mail: dlmaitre@csir.co.za

J. N. Blignaut

South African Environmental Observation Network, Pretoria, South Africa

School of Public Leadership, Stellenbosch University, Stellenbosch, South Africa

A. Clulow · C. S. Everson

Centre for Water Resource Research, Department of Botany and Zoology, University of

KwaZulu-Natal, Pietermaritzburg, South Africa

S. Dzikiti · M. B. Gush

Natural Resources and the Environment, Council for Scientific and Industrial Research, Stellenbosch, South Africa

A. H. M. Görgens

Aurecon, Century City, Cape Town, South Africa

(C) The Author(s) 2020

B. W. van Wilgen et al. (eds.), Biological Invasions in South Africa, Invading

Nature - Springer Series in Invasion Ecology 14,

https://doi.org/10.1007/978-3-030-32394-3_15 
higher than current reductions. This review illustrates the importance of measuring water-use over as wide a range of species as possible, and combining this with information from remote sensing to extrapolate the results to landscapes and catchments. These methods will soon provide much more robust estimates of water use by alien plants at appropriate spatial and temporal scales. The results of these studies can be used in water supply system studies to estimate the impacts on the assured yields. This information can also be used by catchment water resource managers to guide decision-makers when prioritising areas for clearing and rehabilitation, and for targeting species for control measures.

\subsection{Introduction}

South Africa is an arid country with a mean annual rainfall of about $490 \mathrm{~mm}$, only $9 \%$ of which ends up as water in rivers or aquifers (Bailey and Pitman 2015). This situation is exacerbated by the concentration of high rainfall areas in the south and east and low rainfall areas in the western and northern parts (van Wilgen et al. 2020, Chap. 1). Just $8 \%$ of South Africa, Lesotho and Swaziland generates $50 \%$ of the river flows (Nel et al. 2017). The most recent national assessment of the water situation reported that essentially all the reliably available water resources are already in use, so no additional demands can be accommodated (DWAF 2013). The recent droughts across South Africa have highlighted the deteriorating water security situation, and the need to protect water source areas from land cover changes that would decrease usable runoff. One of the key changes is the invasion and replacement of the natural vegetation by invasive alien plant species which alter the vegetation structure and water-use characteristics in ways which can reduce the runoff, or decrease the groundwater recharge.

\subsubsection{Brief History of Concern About Hydrological Impacts}

Among the major invasive alien plants are a wide variety of tree species which were introduced to South Africa over the past few centuries to address timber shortages caused by: (a) the very limited extent of natural forests (Rutherford et al. 2006), and (b) the lack of suitable fast-growing native tree species that are good for timber (Richardson et al. 2003; Le Maitre et al. 2004). The first plantations were in the Western Cape, but soon extended to areas of the Eastern Cape, KwaZulu-Natal, Mpumalanga and Limpopo. Land owners downstream of the plantations on both 
state and private land soon began raising concerns about the drying-up of streams and rivers downstream of the planted areas, concerns which were opposed by the foresters who believed the plantations were not the cause (Bennett and Kruger 2014). These concerns increased following a succession of severe droughts in the 1920s, and testimonies given to Commissions investigating the causes and consequences of the droughts. At the fourth British Empire Forestry Conference in South Africa, a Committee on Forest Influences was established and recommended that a long-term research programme be initiated to determine the impacts of afforestation on water supplies (Wicht 1949; Bennett and Kruger 2014; van Wilgen et al. 2016). This research programme provided unequivocal evidence that tree plantations do reduce runoff relative to the natural vegetation they have replaced, a finding supported by numerous catchment-level studies across the world (van Lill et al. 1980; Bosch and Hewlett 1982; van Wyk 1987; Scott et al. 2004; Farley et al. 2005).

Many of these tree species began to invade the adjacent natural vegetation, a tendency which was initially praised, but later led to concern about their potential impacts on river flows as well as biodiversity (Kruger 1977; van Wilgen et al. 1992, 2016). Although the initial forebodings were raised about tree invasions, they soon extended to the hydrological impacts of species with other growth forms, especially woody plants (Versfeld and van Wilgen 1986). These issues were raised in various forums and were also used to motivate for the first assessment of the hydrological impacts of invasions, which found that they could have a significant impact on Cape Town's water security (Le Maitre et al. 1996). The information from this research, together with other findings, was used to motivate for the establishment of the Working for Water Programme in 1995 (van Wilgen et al. 1998). The programme supported ongoing research into the hydrological impacts of invasions, leading to the first national assessment of their impacts which found that invasions were reducing the naturalised mean annual runoff across South Africa by about 3.30 billion $\mathrm{m}^{3}$ (6.7\% of the country's mean annual runoff) (Le Maitre et al. 2000). It also supported the first assessment of the impacts of Acacia mearnsii (Black Wattle) (Dye et al. 2001; Dye and Jarmain 2004), short-term gains in stream flows following clearing (Dye and Poulter 1995; Prinsloo and Scott 1999), and the first overview of their hydrological impacts (Görgens and van Wilgen 2004).

Many other species with different growth forms were also introduced for various purposes (e.g. fodder, hedges, and horticulture), and invading plant species in South Africa now include the full range from herbaceous annuals and perennials, succulents like cacti, scramblers, shrubs and large trees (Richardson et al. 1997; Henderson 2007). This diversity of invading plant species and growth forms poses a significant challenge to researchers and managers seeking to understand and quantify the hydrological impacts they could have, because there are too many species to investigate individually. We discuss below how this challenge is being addressed, before reviewing the findings of the studies of invasive alien plant impacts to date. 


\subsection{Vegetation and Plant Characteristics and Site-Specific Conditions}

The challenge of trying to bring a broad understanding of how changes in vegetation characteristics can alter the water balance was recognised by Calder (1986, 2005). He developed a conceptual model which posits that plant water-use is limited by a number of their characteristics, provided water availability is limited to water from rainfall (Fig. 15.1). He argued that their size (generally related to their growth-form),

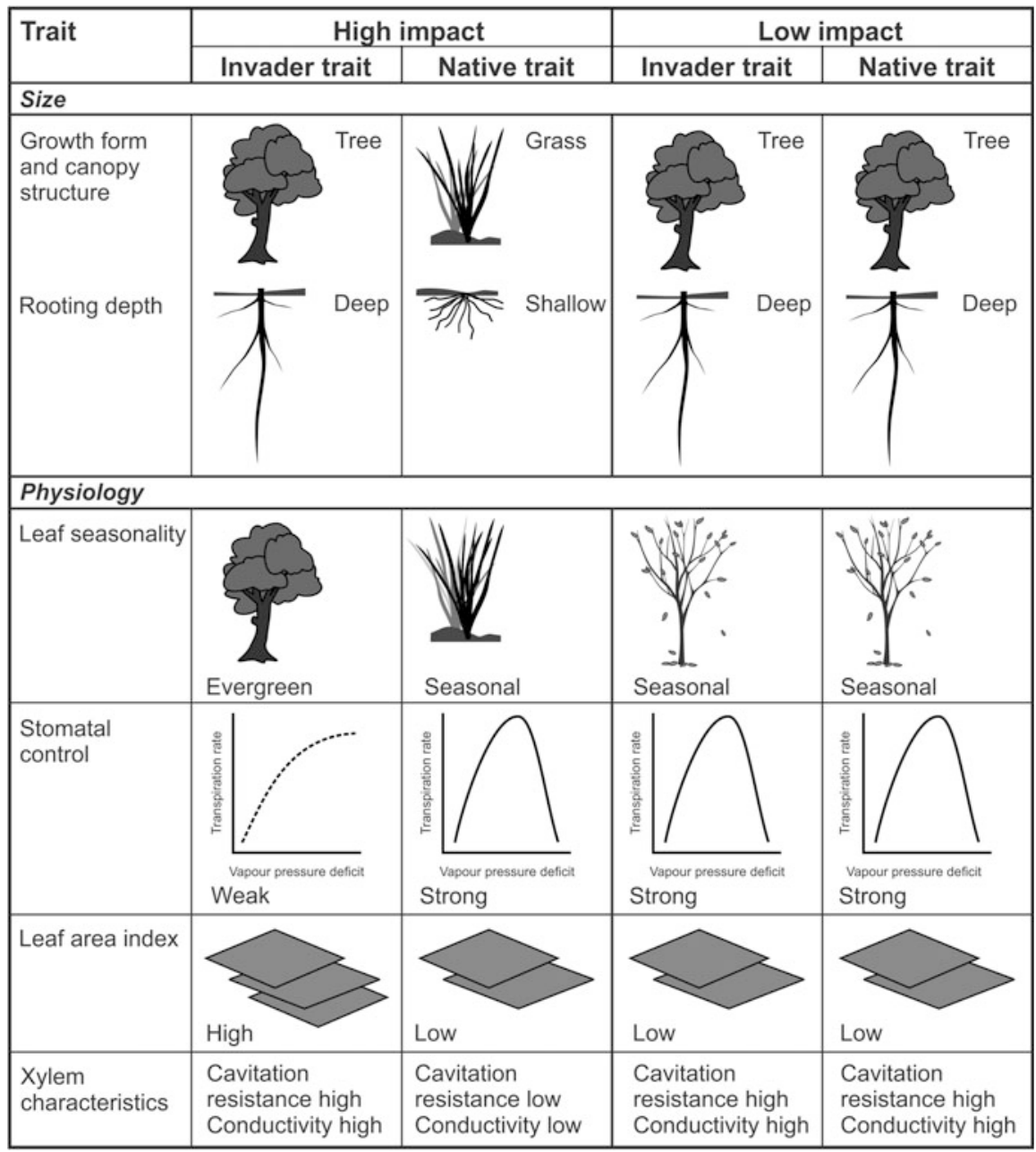

Fig. 15.1 The relationship between the magnitude of the hydrological impacts and the combinations of key plant traits that have been found to influence the impacts of plant invasions on water resources relative to natural vegetation. From Le Maitre et al. (2015b) 
combined with their canopy structure and physiological traits, could explain how changes in dominant plant characteristics could alter runoff. The concept was derived from studies worldwide which have shown that certain kinds of changes in the characteristics of the dominant plants in catchments led to changes in the relationship between rainfall and runoff, indicating shifts in the water balance (Bosch and Hewlett 1982; Zhang et al. 2001).

The limits concept can be applied to invasive plants to provide insights into the likely impacts of invasions replacing natural vegetation in situations where the available water is limited to that from rainfall (Le Maitre 2004; Le Maitre et al. 2015b) (Fig. 15.1). The first distinction is based on plant size, which is linked to growth and associated traits. Trees are taller than grasses so their height exposes them to more light and air movement (Jarvis and McNaughton 1986), and they also tend to have deeper root systems (Canadell et al. 1996; Jackson et al. 1996) which allows them to tap into more of the stored soil moisture than the grasses. So, trees that are invading grasslands will typically cause a large increase in transpiration, and a concomitant reduction in runoff. Where the grasses are seasonal rather than evergreen, and the trees are evergreen, the difference will typically be the greatest. Where the invading and the native trees are similar, the degree of the change in runoff will depend more on differences in physiological traits. For example evergreen trees replacing seasonally deciduous ones are likely to have less impact than seasonally deciduous trees replacing grasses. The shifts can also be more subtle but still have substantial impacts, such as the replacement of native mixtures of annual and perennial plants by invading alien grasses and then by invading thistles (Gerlach 2004).

The limits concept was implicit in models based on biomass and growth-form, which were initially used to estimate the hydrological impacts of invasions as the incremental reductions in streamflow (i.e. the change relative to the natural vegetation). The models grouped the invading species according to their growth forms, linked this to models of biomass versus age for each growth form and, finally, distinguished between riparian and upland invasions (Le Maitre et al. 1996, 2000; van Wilgen et al. 1997). The early models estimated the reductions in runoff in actual amounts (mm per year), which was acceptable in well-watered environments but was problematic as it failed to allow for limitations on water availability to plants, especially in more arid environments. These models were revised and modified to a percentage reduction, again with adjustments for riparian environments (Dzvukamanja et al. 2005; Le Maitre et al. 2013, 2016).

Calder's limits concept was developed for upland or non-riparian environments where the amount of water available is determined primarily by rainfall and the water-holding characteristics of the soil. This is not the case in riparian environments, or where there is shallow groundwater, which means that the plants have access to more water than is supplied by the rainfall. Thus, invasive alien plants in these areas can have substantially higher water-use than those in water-limited upland environments, with the new limits being imposed by factors such as the atmospheric demand or maximum transpiration rates (Le Maitre et al. 2015b). This is 
a concern because there are extensive riparian invasions, particularly in the grasslands and savannas (Le Maitre et al. 2000; van Wilgen et al. 2007).

The dominant vegetation types across the higher rainfall areas of South Africa are savanna and grassland, dominated by shallow-rooted plants with low leaf-areas, many of which are dormant in the dry season. The strategic surface water source areas (SWSAs) of South Africa are high-lying, high-rainfall mountainous areas dominated by grasslands and shrubs, notably fynbos, with isolated patches of native forest (WWF-SA 2013; Le Maitre et al. 2018). Important invaders, particularly in the SWSAs, are the eucalypts, pines and Black Wattle (Acacia mearnsii) used by the commercial forest industry, which covers approximately $1.2 \mathrm{~m}$ ha (Godsmark 2017), or $13 \%$ of these high rainfall environments, and is an important seed source that fuels invasions (Rouget et al. 2003).

These tree species are characteristically deep-rooted, evergreen, with high leaf area and canopy cover (High impact, Fig. 15.1), often differing fundamentally from the natural vegetation they replace, both as individual plants, and when forming stands. The primary impact is an increase in evapotranspiration (ET) relative to the "Baseline" ET of the natural vegetation, resulting in a reduction in streamflow which varies between species (see Sect. 15.3). In the case of groundwater, invasions lead to a reduced recharge and, where the groundwater is within the rooting depth, to direct exploitation of the groundwater (Le Maitre et al. 1999, 2015b). In well-managed plantations their impacts on river flows can be anticipated and sustainably managed. However, when these species invade, particularly in riparian areas, or in areas where they use more water than the original vegetation (e.g. grassland or fynbos), they can have a significant impact on river flows.

\subsection{Modelling Versus Measuring Water Resource Impacts}

A number of methods are available to quantify the water resource impacts of invasive alien plants. These may be broadly divided into measurement techniques and modelling approaches, which can occur at the plant and catchment levels. Catchment scale measurements have used paired catchment studies (involving forest plantations) and soil water balance assessments, while lysimetry can be used for more localised assessments. Sap flow measurement (using techniques such as stem heat balance, heat pulse velocity, or continuously heated probes) are often used to estimate the transpiration of individual plants (Burgess et al. 2001). The ET component can be quantified using micrometeorological and surface energy balance systems (e.g. Bowen ratio, eddy covariance, surface renewal) (Jarmain et al. 2008). These methods measure ET around a flux tower and the flux footprint depends on the height of the sensors above the canopies as well as the prevailing wind speed and direction. Window periods of measurement with sensitive and high maintenance equipment, for approximately 2 weeks at a time during different seasons, has been used recent times (Dye et al. 2008; Jarmain et al. 2008; Clulow et al. 2012, 2013, 2015). Long-term surface renewal systems, which are cheaper and have a lower 
power requirement, have been used to compliment short-term eddy covariance measurements (Clulow et al. 2012). One of the challenges in the quantification of water use by invasive alien plants is that many of the measurement techniques only provide 'point-based' estimates of transpiration or evapotranspiration. Scintillometry overcomes the concerns relating to the 'point-based' and limited 'footprint' scale issue to an extent, as it provides a path averaged estimate of sensible heat flux (Meijninger et al. 2002; Clulow et al. 2011, 2015).

\subsection{Species and Stand-Level Studies}

The impact of specific invasive alien tree species on streamflow has been assessed in field studies, some of which covered extended periods (Table 15.1). These include Acacia mearnsii (Dye and Jarmain 2004; Clulow et al. 2011; Everson et al. 2014), Eucalyptus camaldulensis (River Red Gum) (Dzikiti et al. 2016), Pinus radiata (Monterey Pine) (Dzikiti et al. 2013b), Prosopis species (Dzikiti et al. 2013a, 2017) and Populus canescens (Grey poplars) (Ntshidi et al. 2018). In recent years some studies have also focused on the impacts of the invasive alien plants on groundwater [e.g. Prosopis (Dzikiti et al. 2013a)] although these measurements were also over short periods.

In addition to invasive alien plants, some recent studies have also monitored the water use patterns of co-occurring native vegetation in order quantify the incremental water use by the invasions over and above that of the native vegetation (Dzikiti et al. 2016). Gush and Dye (2015) describe measurements of the water use (transpiration and ET) of a range of native tree species and forest types, and compare these with the water use of introduced tree species. The results show that the water-use of the introduced species is generally higher. Measurements of A. mearnsii growing alongside an afro-temperate forest in the Eastern Cape found that its water-use was about twice that of the native forest species (Scott-Shaw and Everson 2018). A comparison of the water use of Prosopis species with the coexisting and structurally similar native Vachellia karroo (Sweet Thorn) in an arid riparian environment in the Northern Cape found that water use of comparably-sized trees was similar, but the greater density, and more extensive invasions, of Prosopis resulted in much greater impacts on groundwater per unit area (Dzikiti et al. 2017).

Overall, the findings of these studies are that trees invading riparian areas where they have access to additional water, or areas where groundwater can be accessed by their root systems, will transpire substantially more water than those in adjacent dryland areas. The differences between dryland and riparian invasions vary but range from 1.2 to 2 times as much water as the equivalent trees in dryland settings (Le Maitre et al. 2015b, 2016). The Prosopis-Vachellia comparison found that similarly-sized trees transpired similar quantities of water (Dzikiti et al. 2018), but other comparisons of alien and native tree species in riparian settings have found the water-use of the alien trees to be substantially greater (Everson et al. 2011; Gush et al. 2015). 


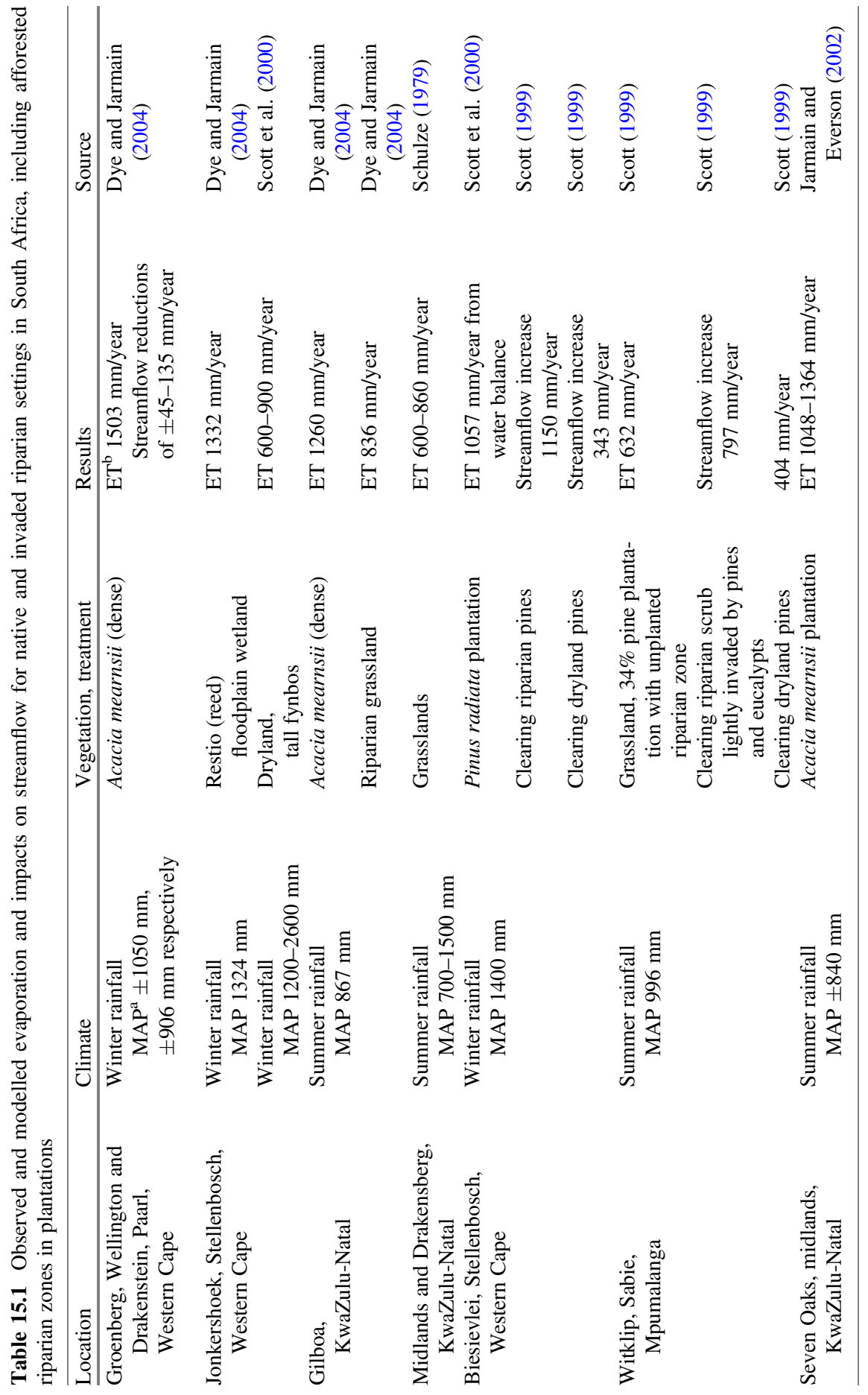




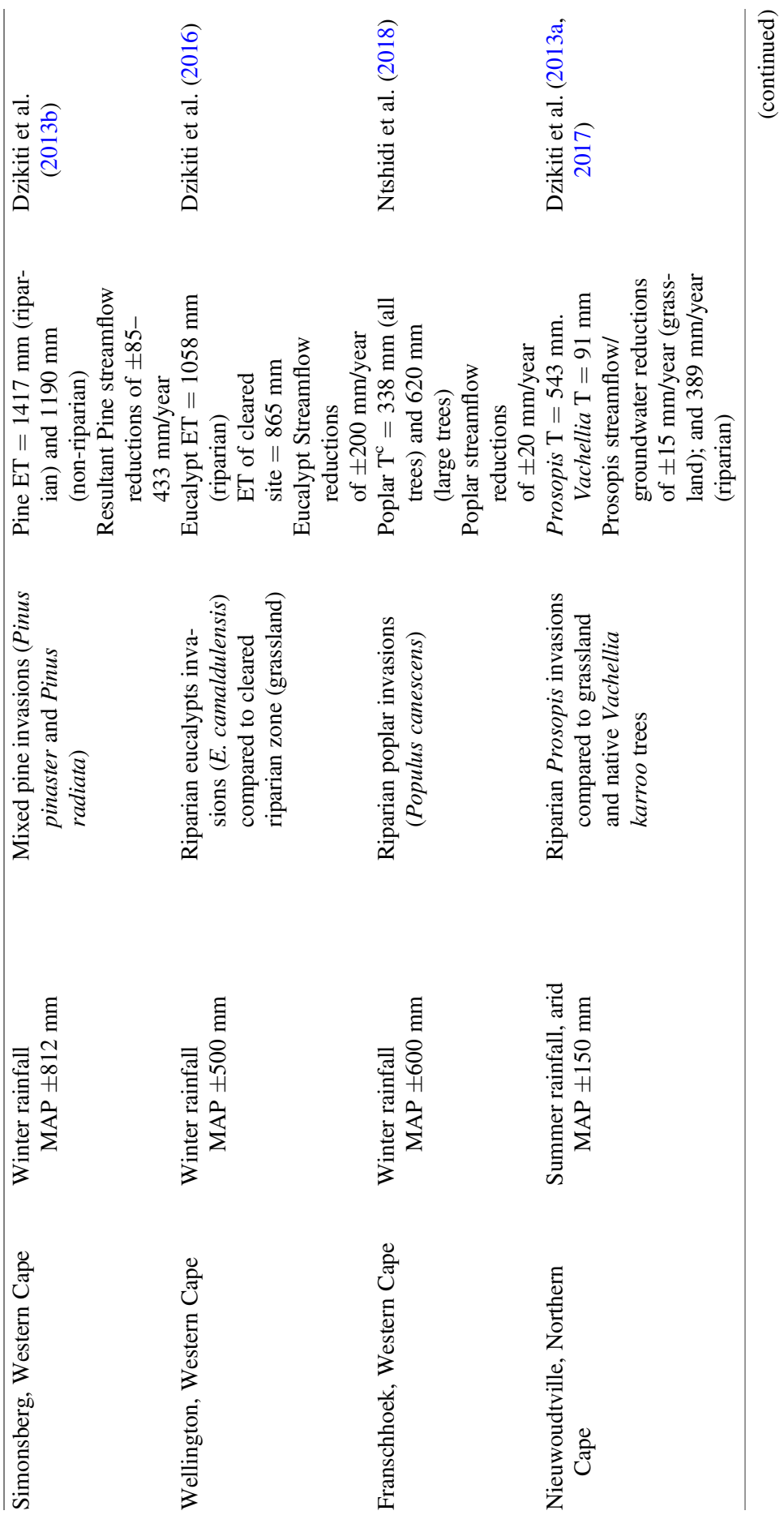




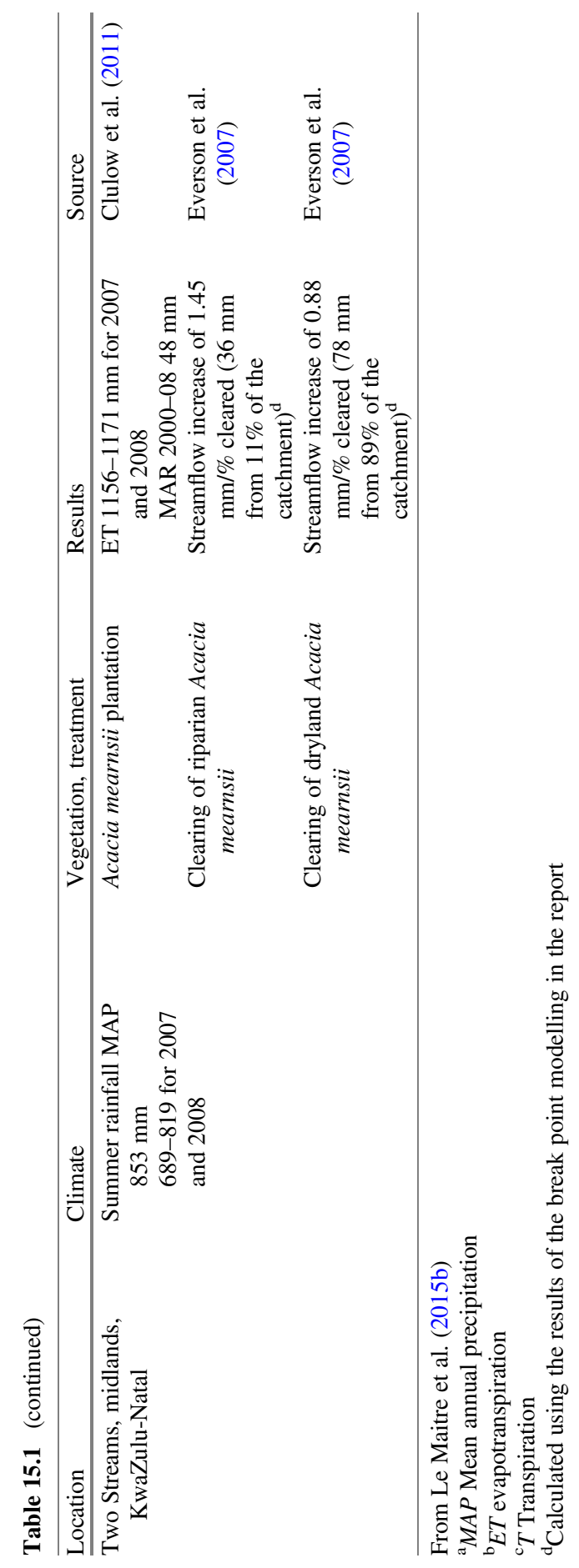




\subsection{Extrapolating to Larger Spatial and Longer Temporal Scales}

Modelling is a commonly applied technique to extrapolate ET or transpiration estimates to larger spatial and longer temporal scales. The availability of observed data to verify the estimates and assumptions involved significantly reduces uncertainty (Allen et al. 1998). Addressing the water resource impacts of invasive alien plants in a truly integrative manner would require researchers to deal with large number of species, typically occurring as mixtures of varying densities, across a range of climates and with access to both groundwater and surface water. One way of assessing this variability at large spatial scales is to use remote sensing data to estimate evapotranspiration from invasive alien plants and contrast them with simultaneous evapotranspiration estimates from native vegetation. This approach does have limitations (e.g. impact of clouds, resolution of images in time and space, requirements for verification on the ground), but also the potential to estimate the water resource impacts of a wide range of invasive alien plants in a consistent manner over a large area, and compare them with other land cover classes (Gibson et al. 2013; Meijninger and Jarmain 2014; van Niekerk et al. 2018). The only study of this type thus far found that the annual evaporation from areas with invading species was greater than from adjacent areas of natural vegetation across both the Western Cape and KwaZulu-Natal (Meijninger and Jarmain 2014). This is consistent with the generally greater water-use observed in the species and stand level studies described above and a promising development. The spatial and temporal resolution of the images is increasing and will make these techniques more robust and useful in the future.

\subsection{Translating Impacts on Runoff to Impacts on Yields}

The implications of streamflow reductions due to alien plant invasions for the assurance of yields from large water supply reservoirs, and bulk surface water resource systems, have been examined in a number of studies over the past two decades (Gillham and Haynes 2001; Larsen et al. 2001; Le Maitre and Görgens 2003; Dzvukamanja et al. 2005; Cullis et al. 2007; Le Maitre et al. 2019). They spanned a range of bioclimatic regions and landscapes across southern Africa and used differing algorithms, hydrological and systems models, actual or hypothetical dams, definitions of yield at a given assurance and levels of invasion, modelling periods and "current" and "future" levels of invasion. Despite the differences in approaches, methodologies and assumptions among these studies, they all found that allowing invasions to continue without any control would result in a significant reduction in system yields (Table 15.2).

The effects of the reductions in runoff into the dams are likely to be greater during droughts, which would magnify the impacts on yields, especially during prolonged 


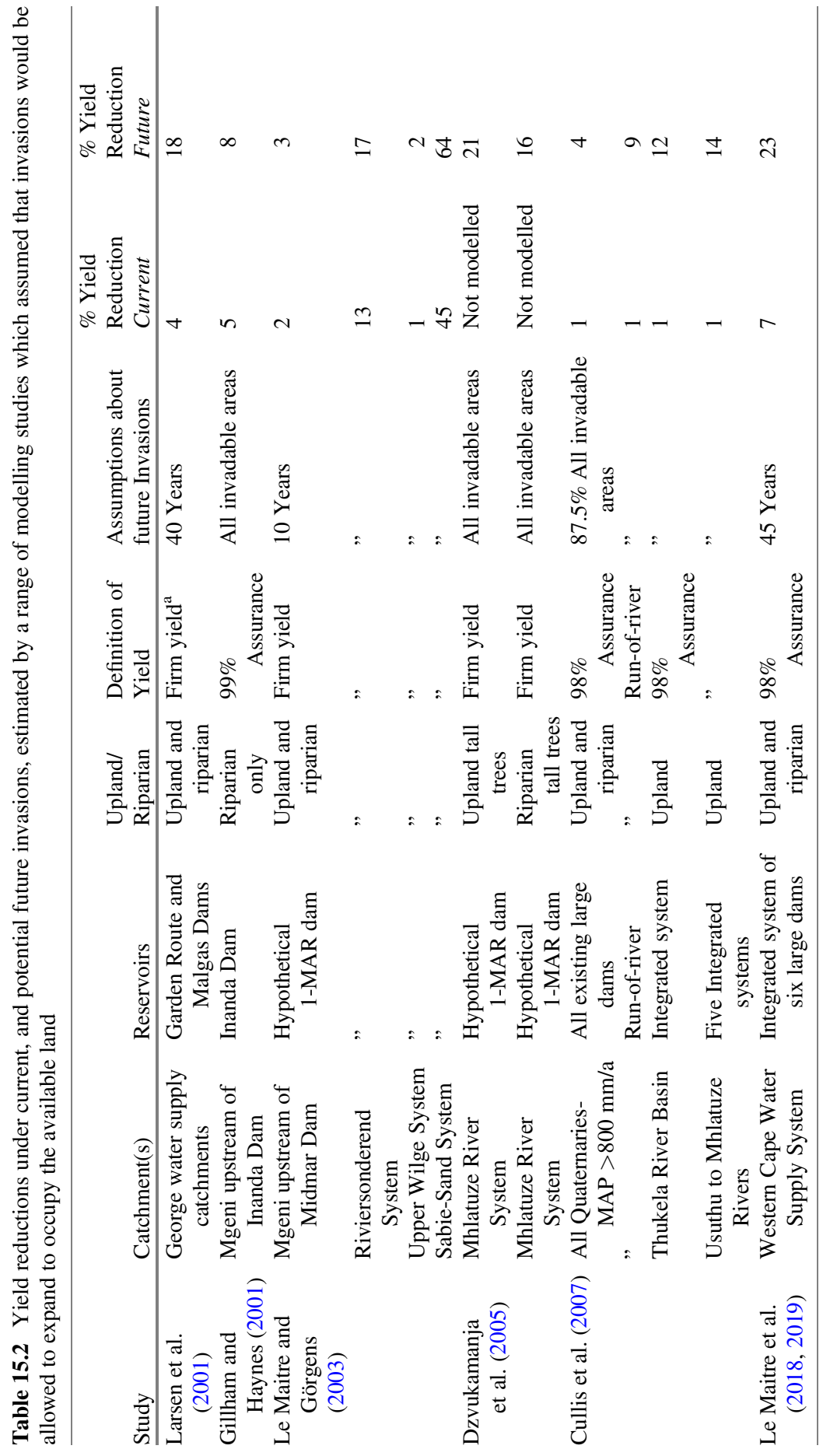




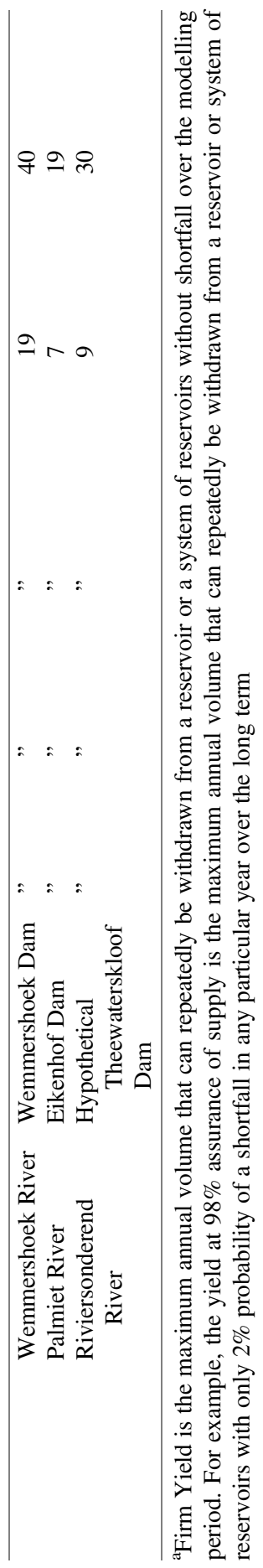


droughts. The current reduction in the yield of the Western Cape Water Supply Scheme due to invading alien plants is estimated to be 38 million $\mathrm{m}^{3}$ per year (Le Maitre et al. 2019). If Cape Town's daily water consumption was $550 \mathrm{Ml}$ per day, then the yield reduction is equivalent to nearly 60 days of supply. In other words, the infamous "Day Zero", the day that dams would essentially run dry, and domestic users would have to collect their own water from supply points, could have been delayed by 60 days. This estimate ignores the cumulative impact of the water used by invasions from the beginning of the drought in 2015 until a date for "Day Zero" was set in 2017.

The one aspect that has been neglected in most of these studies (but see Cullis et al. 2007, Table 15.2), is the potential impact on users who are not supplied by large water supply schemes and dams, but who depend on small water supply systems, abstraction via weirs or diversions, or pumping directly from a river. A similar impact would hold for groundwater users who depend on water pumped from aquifers where the recharge areas have been invaded or where the root systems of invaders can reach the water table. These users have little or no ability to buffer the impacts of invasions on water availability, reducing their water security.

\subsection{Impacts of Potential Invasion Scenarios and Climate Change}

\subsubsection{Invasion Scenarios}

The most recent estimate of the national impacts of invasive alien plants on river flows is that they reduce the MAR by about 1.44 billion $\mathrm{m}^{3} /$ year, or $2.9 \%$ of the naturalised mean annual runoff (less than $50 \%$ of the 3.30 billion $\mathrm{m}^{3} /$ year estimated in 2000) (Le Maitre et al. 2016) (Fig. 15.2). The difference is mainly due to two things: (a) the estimated unit area reduction was $970 \mathrm{~m}^{3} / \mathrm{ha} / \mathrm{year}$ versus the 1998 estimate of $1900 \mathrm{~m}^{3} /$ ha/year, mainly because of updates in the models; and (b) the 2007 mapping resulted in a total condensed invaded area of 1 million ha (Kotzé et al. 2010) compared with 1.76 million ha mapped in 1997. However, the 2007 survey excluded South Africa's arid interior, so the latest results under-estimate the full impacts. In addition, the extent of the high-water-use riparian invasions was underestimated by the 2007 mapping. If the proportion riparian invasions was increased to match those from 1998, this would increase the total reduction by about 1 billion $\mathrm{m}^{3}$ per year (Le Maitre et al. 2016).

The greatest estimated impact is due to wattles (Acacia mearnsii, A. dealbata and A. decurrens) which account for $34 \%$ of the reductions, followed by Pinus species $(19.3 \%)$ and Eucalyptus species (15.8\%) (Le Maitre et al. 2016). Most of the wattle (70\%), eucalypt $(60 \%)$, and pine $(40 \%)$ invasions, and the majority of poplar (Populus) and willow (Salix) invasions occur in the Grassland Biome, which explains why the impacts in this biome are relatively high. Data from 2007 for 


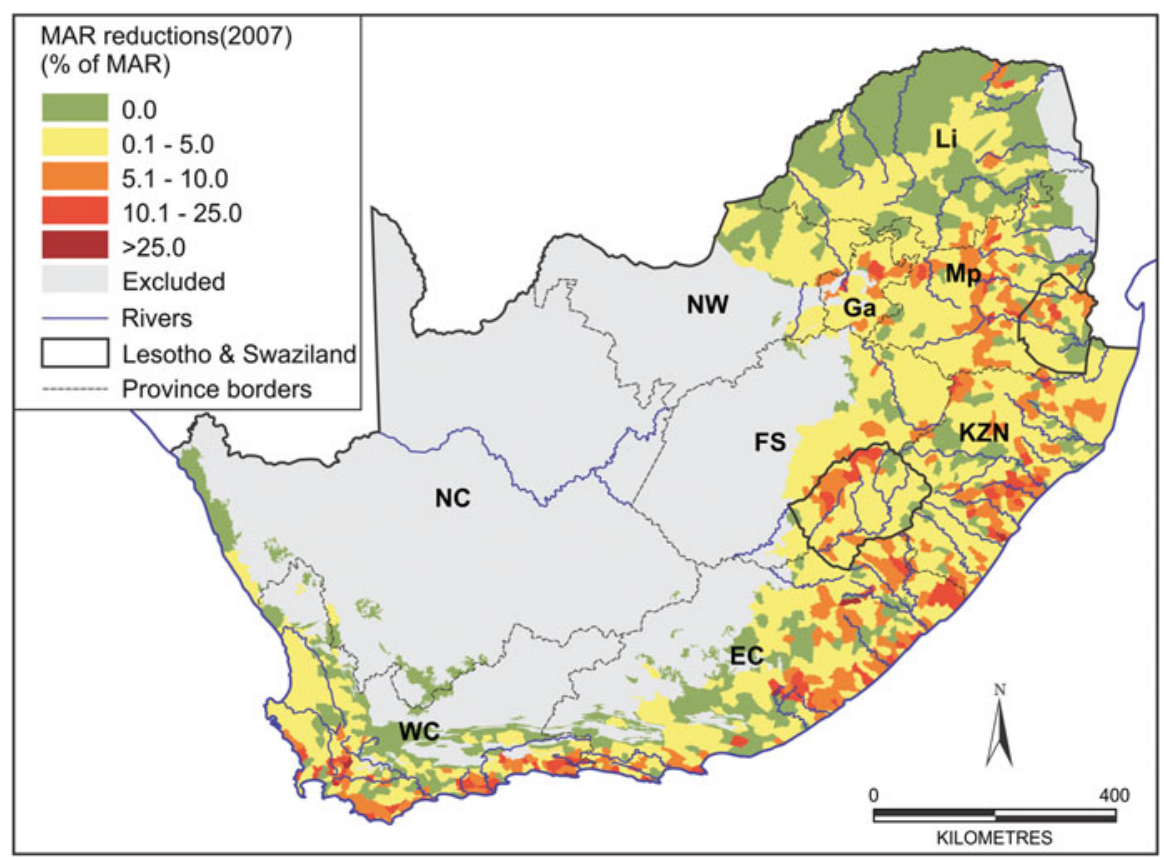

Fig. 15.2 Estimated percentage reductions in the pre-development mean annual runoff per quaternary catchment (Le Maitre et al. 2016) based on invasive alien plant mapping in 2007 (Kotzé et al. 2010). Letters indicate provinces: WC Western Cape, NC Northern Cape, EC Eastern Cape, $K Z N$ KwaZulu-Natal, FS Free State, $N W$ Northwest, Ga Gauteng, Mp Mpumalanga, Li Limpopo

Prosopis invasions in the Northern Cape (van den Berg 2010) suggests they reduce the MAR by about 9 million $\mathrm{m}^{3} / \mathrm{year}$, primarily in the Orange River catchment (Le Maitre et al. 2013). Projections of the invasions in the remaining natural vegetation in the mapped catchments, suggest that the impacts will increase (Le Maitre unpublished data). At an spread rate of 5\%/year and density increase of $1 \% /$ year, the total reduction in MAR would reach \pm 2.59 billion $\mathrm{m}^{3} /$ year $(5.2 \%$ of MAR) in 25 years (i.e. 2032) (Fig. 15.3). At 10\%/year, they would reach \pm 3.15 billion $\mathrm{m}^{3} /$ year by 2032 (6.3\% of MAR). The increases in reductions are spread all through the area mapped in 2007, but are greatest in the high MAR catchments of the Eastern Cape, Kwa-Zulu-Natal and the Western Cape where they will have significant impacts on water security. 


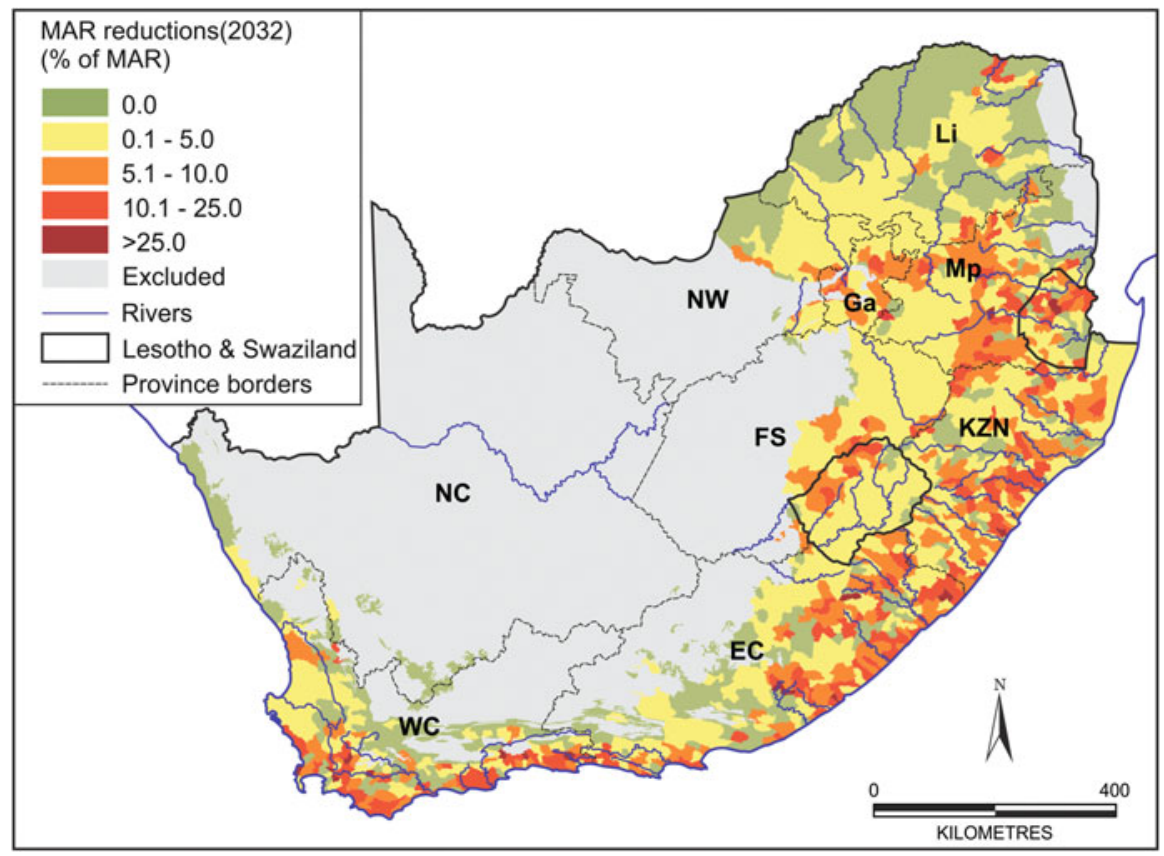

Fig. 15.3 The projected reductions in pre-development MAR by about 2032 if invasions of natural vegetation are allow to continue unmanaged at annual expansion rate of 5\% and densification of $1 \%$ (Le Maitre unpublished data). Letters indicate provinces (see Fig. 15.2)

\subsubsection{Climate Change and Hydrological Impacts of Invasions}

The effects of climate change on the hydrological impacts of invasions have been assessed in three differing but somewhat complementary ways, one being to examine the likely impacts on the major invaders in different biomes, another being to assess the impacts of increasing $\mathrm{CO}_{2}$ concentration, and the third being to compare the effects on the impacts of current invasions under current and future climates.

There have been some studies which have evaluated the impacts of climate change using their understanding of the impacts of climate change at the biome level on invading plant species which are characteristic for particular biomes (Thuiller et al. 2006; Henderson 2007; Richardson et al. 2010; Rouget et al. 2015). Although the impacts of climate change on the Fynbos Biome, and the more arid biomes, were initially predicted to be substantial (Rutherford et al. 1999), more recent predictions suggest less drastic shifts in the west and a significant expansion of the Savanna into the Grassland Biomes (DEA 2013a). However, these projections are based on the direct effects of the changes in climatic conditions. Equally important, if not more so, are the changes in key ecosystem drivers like disturbance regimes, one of which is fire; changes in fire regimes could have a particularly 
marked impacts on the Fynbos Biome (DEA 2015). The projected increases in the numbers of high and extreme fire danger days (Le Maitre et al. 2015a) could, provided there is a suitable source of ignitions, favour fast-maturing invading species and increase invasion rates and impacts in the Fynbos Biome. Fire return intervals in moist grassland and savanna are already short, so changes in fire regimes may not have a significant effect on invasion rates.

Another major driver is the increasing $\mathrm{CO}_{2}$ concentration in the atmosphere which favours woody plant densification (bush encroachment), especially when combined with reduced fuel loads due to grazing (and thus reduced fire intensity) (Bond and Midgley 2000, 2012; O'Connor et al. 2014). There is good evidence that native woody plant densification is taking place throughout the Grassland and Savanna Biomes (Davis-Reddy and Vincent 2017; Skowno et al. 2017), but whether or not the same is happening with invading species in these biomes is not known. Fynbos is associated with low soil nutrients which may limit the response of plants to increased $\mathrm{CO}_{2}$. However, pines have mycorrhizae to harvest nutrients and Australian Acacia species fix nitrogen, so these taxa may become even more aggressive invaders (Richardson et al. 1994). Any gains in water-use efficiency may be offset by their increased invasion rates.

There have not yet been any local studies of the impacts of current invasions under current and future climates, but there are some indications based on the projected changes in climate across South Africa. The most detailed assessment of the implications of climate change for water resources and for their planning is the long-term adaptation scenarios (DEA 2013b). The projected changes are for an increase in runoff along the eastern side of the country and the central interior, with decreases in the west and south-west, including much of the Western Cape. The winter rainfall region, and much of the west, is predicted to experience a combination of increased evaporation and decreased rainfall, and faces the greatest water security risks. Overall the variability of the rainfall will increase and the likelihood of more intense and extended droughts, such as those being experienced across the country at the time of writing, will increase. Given the indications that most of the woody alien plant species, especially the trees species, use more water than the natural vegetation and will, therefore, decrease water availability and water security, it is critical that effective control is achieved.

\subsection{Policy and Governance}

Although the estimated impacts of invasive plants on mean annual runoff have been a key motivation for the Working for Water Programme, no policy or legislative measures have been developed to require their control specifically to limit impacts on water. The legislation that does require invasive alien plant control is either based on their impacts on agricultural resources (excluding water) (DoA 1983) or environmental resources which broadly include water (DEA 2013c). The National Water Act (DWAF 1998) does restrict commercial afforestation, via the Stream Flow 
Reduction Activity measures, to limit impacts on mean annual runoff, but this has never been used to regulate invasions. Despite this limitation, invaded land in the strategic surface water source areas can be made a priority for enforcement and for investment aimed at maximising the water benefits. Prioritisation of areas where the water gains are greatest (Forsyth et al. 2012) is being implemented by the Department of Environment, Forestry and Fisheries, with a new focus on strategic water source areas (Nel et al. 2013; Le Maitre et al. 2018). The importance of prioritising areas to optimise the gains from clearing, including water has been emphasised in a recent assessment of the state of invasions, but there is still a legacy of projects that were initiated in areas which were not optimal (van Wilgen and Wilson 2018). The recently launched Cape Town Water Fund is targeting such areas (Stafford et al. 2019), but the Natural Resource Management programmes need to more actively target such areas.

Recent work has found that public and private sector collaboration in the control of invasive alien plants, and the productive use of the biomass could potentially realise considerable benefits (Mudavanhu et al. 2017b). Clearing of Acacia saligna (Port Jackson) for the production of wood polymer composites could potentially more than offset the costs, while increasing runoff and/or groundwater recharge. Similarly, a public-private partnership and cost-sharing model for the use of biomass for bio-energy production on the Agulhas Plain could result in a net benefit (Stafford and Blignaut 2017). The feasibility of this enterprise depends on the willingness of participants to share the cost for invasive alien plant biomass supply; in this case the bioenergy entrepreneur would invest ZAR154/green tonne and the government ZAR246/green tonne. In both instances, the benefits reported exclude further downstream benefits such as that of the contribution to job creation, Gross Domestic Product (GDP), and the benefits of skills development, the stimulation of rural development, and helping to steer South Africa towards a more sustainable development path. If the potential water flow gains are used to guide the location of these investments, factored in and realised, then such programmes could make a substantial contribution to water security.

\subsection{Financial and Economic Impacts of Water Lost Through Invasions}

From a financial perspective, the opportunity cost of invasive alien plants are: (a) the lost value of production due to a reduction in water resources, and (b) the increased requirement for water supply augmentation schemes, and the earlier development of such schemes. Economically speaking, the impacts of invasive alien plants are much broader because they have an impact on ecosystem functioning, processes, biodiversity, and every aspect of human life and livelihood that depends on them and is affected by them. 
One of the ways to assess the economic impacts is the loss of production capacity due to water-use by invasive alien plants. The value of water is then estimated as the partial derivative of a sector or commodity's production function relative to water (Moolman et al. 2006) and is typically much higher than water tariffs or delivery costs. Not much research has been done on this topic, because research has focused on determining whether invasive alien plant control is the most cost-effective option for a given water supply scheme. This has generally been done using the unit reference value, which provides an estimate of the unit cost of supplying a cubic meter of water at the required assurance over the portion of the water management or augmentation project's lifespan during which it produces economic benefits for society (van Niekerk 2013). It has been used to show that clearing invasive alien plants can be more cost-effective than other water supply options such as building a dam (van Wilgen et al. 1997; Larsen et al. 2001; Hosking and Preez 2002; Marais and Wannenburgh 2008; Blignaut et al. 2010; DWS 2014; Preston 2015; Vundla et al. 2016; Morokong et al. 2016; Mander et al. 2017; Nkambule et al. 2017). None of these studies assessed the financial impacts of impacts on yields (Table 15.2) so this is an opportunity for further research.

Another approach is based on a recent change in international accounting rules which recognises natural capital as an asset, i.e. a stock generating a flow (IASB 2018). Any restoration or improvement of natural capital is, therefore, seen as an investment and not merely an expense. A study using this approach found that a game farm had considerably more value to the company than they thought (Mudavanhu et al. 2017a). Research is needed to evaluate its application to restoration (e.g. clearing of invasions), but this approach could be used to value municipal assets and request transfer payments from National Treasury for management of natural capital-including controlling of invasive alien plants.

\subsection{Conflicts and Controversies Relating to Their Hydrological Impacts and the Impacts of Clearing}

Alien tree species undoubtedly have been of benefit to South Africa-the native forests would have been lost if there had been no plantations to meet the timber and fibre requirements of the country. The industry sustains numerous jobs and a profitable commercial forestry industry, not to mention other services, such as fuelwood and fodder for bees (pollination services) (Forsyth et al. 2004; Shackleton et al. 2007). The location and the extent of plantations managed as commercial forest plantations has been regulated to limit their impacts on water resources since the 1970s, while attempting to meet the country's timber needs (van der Zel 1975). Historically, little has been done to require the industry to address the spread of the same tree species beyond their landholdings, but amendments to the Forestry Stewardship Council's certification systems could change this situation in future (Christine Colvin pers. comm. 2018). 
However, invasions (including those spreading from plantations) can also increase fuel loads and fire intensity and severity, especially where there are coarse dead fuels on the soil surface, potentially leading to severe erosion and flooding downstream (Scott 1993; van Wilgen and Scott 2001; Le Maitre et al. 2014). Dense and closed stands of eucalypts and wattles suppress ground-layer vegetation, altering infiltration and reducing soil stabilisation, leading to increases in erosion, potentially decreasing water quality and increasing sedimentation of dams (van der Waal et al. 2012) and reducing grazing capacity (Yapi 2013).

Although long-term catchment studies have demonstrated the impacts of plantations on mean annual runoff, the major invading tree species are the same as those in the plantations, and reach comparable stand densities and stature, the Department of Water Affairs and Sanitation has not acknowledged that the impacts of invasions can be as significant as plantations. A good example is the impacts of invasions on the yields from water supply systems (Table 15.2). These impacts have not been explicitly taken into account in supply augmentation plans, except for Berg River Dam and De Hoop Dam where control measures were included in the construction budgets (Preston et al. 2018). The growing body of evidence supporting reductions in yields should inform any future decisions about water supply systems as well as motivating for effective invasive alien plant control measures as part of the maintenance.

Acknowledgements We thank the Natural Resource Management Programmes and the Working for water Programme for funding and supporting much of the research that has been reviewed for this chapter.

\section{References}

Allen R, Pereira L, Raes D, Smith M (1998) Crop evapotranspiration: guidelines for computing crop water requirements. FAO Irrigation and Drainage Paper No. 56, FAO, Rome

Bailey AK, Pitman WV (2015) WR2012 Study User's Guide Version 1. Water Resources of South Africa 2012 Study (WR2012). Report K5/2143/1, Water Research Commission, Pretoria

Bennett BM, Kruger FJ (2014) Forestry and water conservation in South Africa: history, science and policy. ANU E Press, The Australian National University, Canberra. https://doi.org/10. 22459/FWCSA.11.2015

Blignaut J, Mander M, Schulze R et al (2010) Restoring and managing natural capital towards fostering economic development: evidence from the Drakensberg, South Africa. Ecol Econ 69:1313-1323. https://doi.org/10.1016/j.ecolecon.2010.01.007

Bond WJ, Midgley GF (2000) A proposed $\mathrm{CO}_{2}$-controlled mechanism of woody plant invasion in grasslands and savannas. Glob Chang Biol 6:865-869. https://doi.org/10.1046/j.1365-2486. 2000.00365.x

Bond WJ, Midgley GF (2012) Carbon dioxide and the uneasy interactions of trees and savannah grasses. Philos Trans R Soc Lond Ser B Biol Sci 367:601-612. https://doi.org/10.1098/rstb. 2011.0182

Bosch JM, Hewlett JD (1982) A review of catchment experiments to determine the effect of vegetation changes on water yield and evapotranspiration. J Hydrol 55:3-23. https://doi.org/ $10.1016 / 0022-1694(82) 90117-2$ 
Burgess SSO, Adams MA, Turner NC et al (2001) An improved heat pulse method to measure low and reverse rates of sap flow in woody plants. Tree Physiol 21:589-598. https://doi.org/10.1093/ treephys/21.9.589

Calder IR (1986) What are the limits on forest evaporation? - comment. J Hydrol 82:179-192. https://doi.org/10.1016/0022-1694(85)90053-8

Calder IR (2005) The blue revolution: land use and integrated water resources management, 2nd edn. Earthscan, London

Canadell J, Jackson RB, Ehleringer JR et al (1996) Maximum rooting depth of vegetation types at the global scale. Oecologia 108:583-595. https://doi.org/10.1007/BF00329030

Clulow AD, Everson CS, Gush MB (2011) The long-term impact of Acacia mearnsii trees on evaporation, streamflow and groundwater resources. Report No. TT 505/11, Water Research Commission, Pretoria

Clulow AD, Everson CS, Mengistu MG et al (2012) Measurement and modelling of evaporation from a coastal wetland in Maputaland, South Africa. Hydrol Earth Syst Sci Discuss 9:1741-1782. https://doi.org/10.5194/hessd-9-1741-2012

Clulow AD, Everson CS, Price JS et al (2013) Water-use dynamics of a peat swamp forest and a dune forest in Maputaland, South Africa. Hydrol Earth Syst Sci 17:2053-2067. https://doi.org/ 10.5194/hess-17-2053-2013

Clulow AD, Everson CS, Mengistu MG et al (2015) Extending periodic eddy covariance latent heat fluxes through tree sap-flow measurements to estimate long-term total evaporation in a peat swamp forest. Hydrol Earth Syst Sci 19:2513-2534. https://doi.org/10.5194/hess-19-2513-2015

Cullis JDS, Görgens AHM, Marais C (2007) A strategic study of the impact of invasive alien plants in the high rainfall catchments and riparian zones of South Africa on total surface water yield. Water SA 33:35-42. https://doi.org/10.4314/wsa.v33i1.47869

Davis-Reddy CL, Vincent K (2017) Climate risk and vulnerability. A handbook for Southern Africa, 2nd edn. CSIR, Pretoria

DEA (2013a) Long-Term Adaptation Scenarios Flagship Research Programme (LTAS) for South Africa. Climate trends and scenarios for South Africa. Department of Environmental Affairs, Pretoria

DEA (2013b) Climate change implications for the water sector in South Africa. LTAS Phase 1, Technical report (no. 2 of 6). Department of Environmental Affairs, Pretoria

DEA (2013c) National environmental management: Biodiversity Act (10/2004): Alien and Invasive Species Regulations No R. 506. Department of Environmental Affairs, Pretoria

DEA (2015) Climate change adaptation plans for South African Biomes. In: Kharika JRM, Mkhize NCS, Munyai T, Khavhagali VP, Davis C, Dziba D, Scholes R, van Garderen E, von Maltitz G, Le Maitre D, Archibald S, Lotter D, van Deventer H, Midgely G, Hoffman T (eds). Department of Environmental Affairs, Pretoria

DoA (1983) Conservation of Agricultural Resources Act

DWAF (1998) National Water Act. Act No 36 of 1998, Department of Water Affairs, Pretoria

DWAF (2013) National water resource strategy. Water for an equitable and sustainable future. Department of Water Affairs and Forestry, Pretoria

DWS (2014) Feasibility study for the Mzimvubu Water Project: cost estimates and economic analysis. Report No: P WMA 12/T30/00/5212/15, Department of Water and Sanitation, Pretoria

Dye P, Jarmain C (2004) Water use by black wattle (Acacia mearnsii): implications for the link between removal of invading trees and catchment streamflow response. S Afr J Sci 100:40-44

Dye PJ, Poulter AG (1995) A field demonstration of the effect on streamflow of clearing of invasive pine and wattle trees from a riparian zone. South Afr For J 173:27-30. https://doi.org/10.1080/ 00382167.1995.9629687

Dye P, Moses G, Vilakazi P et al (2001) Comparative water use of wattle thickets and indigenous plant communities at riparian sites in the Western Cape and KwaZulu-Natal. Water SA 27:529-538. https://doi.org/10.4314/wsa.v27i4.4967 
Dye PJ, Gush MB, Everson CS et al (2008) Water use in relation to biomass of indigenous tree species in woodland, forest and/or plantation conditions. Research Report No.TT361/08, Water Research Commission, Pretoria

Dzikiti S, Schachtschneider K, Naiken V et al (2013a) Water relations and the effects of clearing invasive Prosopis trees on groundwater in an arid environment in the Northern Cape, South Africa. J Arid Environ 90:103-113. https://doi.org/10.1016/j.jaridenv.2012.10.015

Dzikiti S, Schachtschneider K, Naiken V et al (2013b) Comparison of water-use by alien invasive pine trees growing in riparian and non-riparian zones in the Western Cape Province, South Africa. For Ecol Manag 293:92-102. https://doi.org/10.1016/j.foreco.2013.01.003

Dzikiti S, Gush MB, Le Maitre DC et al (2016) Quantifying potential water savings from clearing invasive alien Eucalyptus camaldulensis using in situ and high resolution remote sensing data in the Berg River Catchment, Western Cape, South Africa. For Ecol Manag 361:69-80. https://doi. org/10.1016/j.foreco.2015.11.009

Dzikiti S, Ntshidi Z, Le Maitre DC et al (2017) Assessing water use by Prosopis invasions and Vachellia karroo trees: implications for groundwater recovery following alien plant removal in an arid catchment in South Africa. For Ecol Manag 398:153-163. https://doi.org/10.1016/j. foreco.2017.05.009

Dzikiti S, Bugan R, Le Maitre D et al (2018) Comparison of water use by Prosopis spp. and the co-occurring Vachellia karroo trees before and after clearing the invasions: implications on groundwater. Report No 2256/1/18, Water Research Commission, Pretoria

Dzvukamanja TN, Görgens AHM, Jonker V (2005) Streamflow reduction modelling in water resource analysis. Report No. 1221/1/05, Water Research Commission, Pretoria

Everson CS, Gush MB, Moodley M, et al (2007) Effective management of the riparian zone vegetation to significantly reduce the cost of catchment management and enable greater productivity of land resources. Report No. 1284/1/07, Water Research Commission, Pretoria

Everson CS, Dye PJ, Gush MB, Everson TM (2011) Water use of grasslands, agroforestry systems and indigenous forests. Water SA 37:781-788. https://doi.org/10.4314/wsa.v37i5.15

Everson CS, Clulow AD, Becker M, et al (2014) The long term impact of Acacia mearnsii trees on evaporation, streamflow, low flows and ground water resources. Phase II: Understanding the controlling environmental variables and soil water processes over a full crop rotation. Report No. 2022/1/13, Water Research Commission, Pretoria

Farley KA, Jobbágy EG, Jackson RB (2005) Effects of afforestation on water yield: a global synthesis with implications for policy. Glob Chang Biol 11:1565-1576. https://doi.org/10.1111/ j.1365-2486.2005.01011.x

Forsyth GG, Richardson DM, Brown PJ, van Wilgen BW (2004) A rapid assessment of the invasive status of Eucalyptus species in two South African provinces. S Afr J Sci 100:75-77

Forsyth GG, Le Maitre DC, O'Farrell PJ, van Wilgen BW (2012) The prioritisation of invasive alien plant control projects using a multi-criteria decision model informed by stakeholder input and spatial data. J Environ Manag 103:51-57. https://doi.org/10.1016/j.jenvman.2012.01.034

Gerlach JD (2004) The impacts of serial land-use changes and biological invasions on soil water resources in California, USA. J Arid Environ 57:365-379. https://doi.org/10.1016/S0140-1963 (03)00102-2

Gibson LA, Jarmain C, Su Z, Eckardt FE (2013) Estimating evapotranspiration using remote sensing and the surface energy balance system - a South African perspective. Water SA 39:477-484. https://doi.org/10.4314/wsa.v39i4.5

Gillham S, Haynes M (2001) Is the clearing of riparian alien invasive vegetation a viable water resources management strategy? In: Regional management of water resources (Proceedings of a symposium held during the Sixth IAHS Scientific Assembly at Maastricht, The Netherlands, July 2001). IAHS Publ. no. 268, Proceedings of the International Association of Hydrological Sciences, IAHS, UK, pp 139-145

Godsmark R (2017) The South African forestry and forest products industry -2016 . Produced by Forestry South Africa (FSA), Johannesburg 
Görgens AHM, van Wilgen BW (2004) Invasive alien plants and water resources in South Africa: current understanding, predictive ability and research challenges. S Afr J Sci 100:27-33

Gush MB, Dye PJ (2015) Water use and socio-economic benefit of the biomass of indigenous trees, vol 2. Site-specific technical report. Report No. 1876/2/15, Water Research Commission, Pretoria

Gush MB, Lange WJ, De Dye PJ, Geldenhuys CJ (2015) Water use and socio-economic benefit of the biomass of indigenous trees, vol 1. Research Report. Report no. 1876/1/15, Water Research Commission, Pretoria

Henderson L (2007) Invasive, naturalized and casual alien plants in southern Africa: a summary based on the Southern African Plant Invaders Atlas (SAPIA). Bothalia 37:215-248. https://doi. org/10.4102/abc.v37i2.322

Hosking SG, Preez M (2002) Valuing water gains in the Eastern Cape's working for water programme. Water SA 28:23-28. https://doi.org/10.4314/wsa.v28i1.4863

IASB (2018) Conceptual framework for financial reporting. International Accounting Standards Board, London

Jackson RB, Canadell J, Ehleringer JR et al (1996) A global analysis of root distributions for terrestrial biomes. Oecologia 108:389-411. https://doi.org/10.1007/BF00333714

Jarmain C, Everson CS (2002) Comparative evaporation measurements above commercial forestry and sugarcane canopies in the KwaZulu-Natal Midlands commercial forestry and sugarcane canopies in the KwaZulu-Natal Midlands. Pretoria

Jarmain C, Everson CS, Savage MJ et al (2008) Refining tools for evaporation monitoring in support of water resources management. Report No. 1567/1/08, Water Research Commission, Pretoria

Jarvis PG, McNaughton KG (1986) Stomatal control of transpiration: scaling up from leaf to region. Adv Ecol Res 12:1-49. https://doi.org/10.1016/S0065-2504(08)60119-1

Kotzé I, Beukes H, van den Berg E, Newby T (2010) National invasive alien plant survey. Report No. GW/A/2010/21, Agricultural Research Council - Institute for Soil, Climate and Water, Pretoria

Kruger FJ (1977) Invasive woody plants in Cape fynbos with special reference to the biology and control of Pinus pinaster. In: Proceedings of the second national weeds conference of South Africa. Weed Society, pp 54-74

Larsen J, Marais C, Görgens AHM (2001) Water resources planning with recognition of alien vegetation. In: Tenth South African national hydrological symposium, 26-28 Sept 2001, p 12

Le Maitre DC (2004) Predicting invasive species impacts on hydrological processes: the consequences of plant physiology for landscape processes. Weed Technol 18:1408-1410. https://doi. org/10.1614/0890-037X(2004)018[1408:PISIOH]2.0.CO;2

Le Maitre D, Görgens A (2003) Impact of invasive alien vegetation on dam yields. Report No. KV 141/03b, Water Research Commission, Pretoria

Le Maitre DC, van Wilgen BW, Chapman RA, McKelly D (1996) Invasive plants and water resources in the Western Cape Province, South Africa: modelling the consequences of a lack of management. J Appl Ecol 33:161-172. https://doi.org/10.2307/2405025

Le Maitre DC, Scott DF, Colvin C (1999) A review of information on interactions between vegetation and groundwater. Water SA 25:137-152

Le Maitre DC, Versfeld DB, Chapman RA (2000) The impact of invading alien plants on surface water resources in South Africa: a preliminary assessment. Water SA 26:397-408

Le Maitre DC, Richardson DM, Chapman RA (2004) Alien plant invasions in South Africa: driving forces and the human dimension. S Afr J Sci 100:103-112

Le Maitre DC, Forsyth GG, Dzikiti S, Gush MB (2013) Estimates of the impacts of invasive alien plants on water flows in South Africa. Report No. CSIR/NRE/ECO/ER/2013/0067/B, Natural Resources and the Environment, CSIR, Stellenbosch

Le Maitre DC, Kotzee IM, O'Farrell PJ (2014) Impacts of land-cover change on the water flow regulation ecosystem service: invasive alien plants, fire and their policy implications. Land Use Policy 36:171-181. https://doi.org/10.1016/j.landusepol.2013.07.007 
Le Maitre DC, Forsyth GG, Engelbrecht F et al (2015a) Climate, fire regimes and fire danger. Information management, fire research \& modelling and fire risk assessment component, GEF Fynbosfire Project. Report No CSIR/NRE/ECOS/ER/2015/0079/B, Natural Resources and the Environment, CSIR, Stellenbosch

Le Maitre DC, Gush MB, Dzikiti S (2015b) Impacts of invading alien plant species on water flows at stand and catchment scales. AoB Plants 7:plv043. https://doi.org/10.1093/aobpla/plv043

Le Maitre DC, Forsyth GG, Dzikiti S, Gush MB (2016) Estimates of the impacts of invasive alien plants on water flows in South Africa. Water SA 42:659. https://doi.org/10.4314/wsa.v42i4.17

Le Maitre DC, Görgens AHM, Howard G, Walker N (2019) Impacts of alien plant invasions on water resources and yields from the Western Cape Water Supply System (WCWSS). Water SA 45:568-579. https://doi.org/10.17159/wsa/2019.v45.i4.7538

Le Maitre DC, Seyler H, Holland M, et al (2018) Identification, delineation and importance of the strategic water source areas of South Africa, Lesotho and Swaziland for Surface Water and Groundwater. Final Integrated Report on Project K5/2431, Water Research Commission, Pretoria

Mander M, Jewitt G, Dini J et al (2017) Modelling potential hydrological returns from investing in ecological infrastructure: case studies from the Baviaanskloof-Tsitsikamma and uMngeni catchments, South Africa. Ecosyst Serv 27:261-271. https://doi.org/10.1016/j.ecoser.2017.03. 003

Marais C, Wannenburgh AM (2008) Restoration of water resources (natural capital) through the clearing of invasive alien plants from riparian areas in South Africa-costs and water benefits. South Afr J Bot 74:526-537. https://doi.org/10.1016/j.sajb.2008.01.175

Meijninger WML, Jarmain C (2014) Satellite-based annual evaporation estimates of invasive alien plant species and native vegetation in South Africa. Water SA 40:95-107. https://doi.org/10. 4314/wsa.v40i1.12

Meijninger WML, Hartogensis OK, Kohsiek W et al (2002) Determination of area-averaged sensible heat fluxes with a large aperture scintillometer over a heterogeneous surface - Flevoland field experiment. Bound-Layer Meteorol 10:63-83. https://doi.org/10.1023/ A:1019683616097

Moolman CE, Blignaut JN, van Eyden R (2006) Modelling the marginal revenue of water in selected agricultural commodities: a panel data approach. Agrekon 45:78-88. https://doi.org/10. 1080/03031853.2006.9523735

Morokong T, Blignaut J, Nkambule $\mathrm{N}$ et al (2016) Clearing invasive alien plants as a cost-effective strategy for water catchment management: the case of the Olifants River catchment, South Africa. South Afr J Econ Manag Sci 19. https://doi.org/10.4102/sajems.v19i5.1594

Mudavanhu S, Blignaut J, Stegmann N et al (2017a) The economic value of ecosystem goods and services: the case of Mogale's Gate Biodiversity Centre, South Africa. Ecosyst Serv 26:127-136. https://doi.org/10.1016/J.ECOSER.2017.06.005

Mudavanhu S, Blignaut JN, Vink N et al (2017b) An assessment of the costs and benefits of using Acacia saligna (Port Jackson) and recycled thermoplastics for the production of wood polymer composites in the Western Cape province, South Africa. Afr J Agric Resour Econ 12:322-365

Nel JL, Smith J, Le Maitre D (2013) Strategic water source areas: linking supply to urban water demand. Final Report for Component 1, Task 1.1.3. Produced by the CSIR for the ProEcoserv Project, Natural Resources and the Environment, CSIR

Nel JL, Le Maitre DC, Roux DJ, et al (2017) Strategic water source areas for urban water security: making the connection between protecting ecosystems and benefiting from their services. Ecosyst Serv 28:251-259. https://doi.org/10.1016/j.ecoser.2017.07.013

Nkambule NP, Blignaut JN, Vundla T et al (2017) The benefits and costs of clearing invasive alien plants in northern Zululand, South Africa. Ecosyst Serv 27:203-223. https://doi.org/10.1016/j. ecoser.2017.04.011

Ntshidi Z, Gush MB, Dzikiti D, Le Maitre DC (2018) Characterising the water use and hydraulic properties of riparian tree invasions: a case study of Populus canescens in South Africa. Water SA 44:328-337. https://doi.org/10.4314/wsa.v44i2.18 
O’Connor TG, Puttick JR, Hoffman MT (2014) Bush encroachment in southern Africa: changes and causes. Afr J Range Forage Sci 31:67-88. https://doi.org/10.2989/10220119.2014.939996

Preston IR (2015) Water supply development decision-making in South Africa. Rhodes University, Grahamstown

Preston IR, Le Maitre DC, Blignaut JN et al (2018) Impact of invasive alien plants on water provision in selected catchments. Water SA 44:719. https://doi.org/10.4314/wsa.v44i4.20

Prinsloo FW, Scott DF (1999) Streamflow responses to the clearing of alien invasive trees from riparian zones at three sites in the Western Cape Province. South African For J 185:1-7. https:// doi.org/10.1080/10295925.1999.9631220

Richardson DM, Allsopp N, D'Antonio CM et al (1994) Plant invasions - the role of mutualisms. Biol Rev 75:65-93. https://doi.org/10.1111/j.1469-185X.1999.tb00041.x

Richardson DM, Macdonald IAW, Hoffmann JH, Henderson L (1997) Alien plant invasions. In: Cowling RM, Richardson DM, Pierce SM (eds) Vegetation of Southern Africa. Cambridge University Press, Cambridge, pp 535-570

Richardson DM, Cambray JA, Chapman RA et al (2003) Vectors and pathways of biological invasions in South Africa - past, present, and future. In: Ruiz G, Carlton J (eds) Invasive species: vectors and management strategies, 1st edn. Island Press, Washington, DC, pp 292-349

Richardson DM, Iponga DM, Roura-Pascual N et al (2010) Accommodating scenarios of climate change and management in modelling the distribution of the invasive tree Schinus molle in South Africa. Ecography (Cop) 33:1049-1061. https://doi.org/10.1111/j.1600-0587.2010. 06350.x

Rouget M, Richardson DM, Nel JL, van Wilgen BW (2003) Commercially important trees as invasive aliens - towards spatially explicit risk assessment at a national scale. Biol Invasions 4:397-412. https://doi.org/10.1023/A:1023611713339

Rouget M, Hui C, Renteria J et al (2015) Plant invasions as a biogeographical assay: vegetation biomes constrain the distribution of invasive alien species assemblages. South Afr J Bot 101:24-31. https://doi.org/10.1016/j.sajb.2015.04.009

Rutherford MC, Midgley GF, Bond WJ et al (1999) South African country study on climate change. Plant biodiversity: vulnerability and adaptation assessment. National Botanical Institute, Cape Town

Rutherford MC, Mucina L, Powrie LW (2006) Biomes and bioregions of Southern Africa. In: Mucina L, Rutherford MC (eds) The vegetation of South Africa, Lesotho and Swaziland. Strelitzia 19. South African National Biodiversity Institute, Pretoria, pp 32-51

Schulze RE (1979) Hydrology and water resources of the Drakensberg. Natal Town and Regional Planning Commission, Pietermaritzburg

Scott DF (1993) The hydrological effects of fire in South African mountain catchments. J Hydrol 150:409-432. https://doi.org/10.1016/0022-1694(93)90119-T

Scott DF (1999) Managing riparian zone vegetation to sustain streamflow: results of paired catchment studies in South Africa. Can J For Res 29:1149-1157. https://doi.org/10.1139/x99042

Scott DF, Prinsloo FW, Moses G et al (2000) A re-analysis of the South African catchment afforestation experimental data. Report No. 810/1/00, Water Research Commission, Pretoria

Scott DF, Bruijnzeel LA, Vertessy R, Calder IR (2004) Forest hydrology: impacts of forest plantations on streamflow. In: Burley J, Evans J, Youngquist JA (eds) The encyclopedia of forest sciences. Elsevier, Oxford, pp 367-377. https://doi.org/10.1016/B0-12-145160-7/002726

Scott-Shaw BC, Everson CS (2018) Water-use dynamics of an alien invaded riparian forest within the summer rainfall zone of South Africa. Hydrol Earth Syst Sci:1-21. https://doi.org/10.5194/ hess-2018-227-AC5

Shackleton CM, McGarry D, Fourie S et al (2007) Assessing the effects of invasive alien species on rural livelihoods: case examples and a framework from South Africa. Hum Ecol 35:113-127. https://doi.org/10.1007/s10745-006-9095-0 
Skowno AL, Thompson MW, Hiestermann J et al (2017) Woodland expansion in South African grassy biomes based on satellite observations (1990-2013): general patterns and potential drivers. Glob Chang Biol 23:2358-2369. https://doi.org/10.1111/gcb.13529

Stafford W, Blignaut J (2017) Reducing landscape restoration costs: feasibility of generating electricity from invasive alien plant biomass on the Agulhas Plain, South Africa. Ecosyst Serv 27:224-231. https://doi.org/10.1016/j.ecoser.2017.04.008

Stafford L, Shemie D, Kroeger T et al (2019) Greater Cape Town water fund business case. Assessing the return on investment for ecological infrastructure restoration, April 2019. The Nature Conservancy, Cape Town

Thuiller W, Richardson DM, Rouget M et al (2006) Interactions between environment, species traits, and human uses describe patterns of plant invasions. Ecology 87:1755-1769. https://doi. org/10.1890/0012-9658(2006)87[1755:IBESTA]2.0.CO;2

van den Berg E (2010) Detection, quantification and monitoring Prosopis spp. in the Northern Cape Province of South Africa using remote sensing and GIS. North-West University, Potchefstroom van der Waal BW, Rowntree KM, Radloff SE (2012) The effect of Acacia mearnsii invasion and clearing on soil loss in the Kouga mountains, Eastern Cape, South Africa. L Degrad Dev 23:577-585. https://doi.org/10.1002/ldr.2172

van der Zel DW (1975) Results of the multiple catchment experiments at the Jonkershoek Research station, South Africa. 2. Influence of protection of fynbos on stream discharge in Langrivier. For South Africa 16:13-18

van Lill WS, Kruger FJ, van Wyk DB (1980) Streamflow responses to afforestation with Eucalyptus grandis Hill Ex Maiden and Pinus patula Schlecht. Et Cham. on streamflow from experimental catchments at Mokobulaan, Traansvaal. J Hydrol 45:107-118. https://doi.org/10.1016/00221694(80)90069-4

van Niekerk PH (2013) Hydrologic-economic appraisal of inter-basin water transfer projects. Stellenbosch University, Stellenbosch. https://doi.org/10.4314/wsa.v39i4.13

van Niekerk A, Jarmain C, Goudriaan R et al (2018) An earth observation approach towards mapping irrigated area and quantifying water use by irrigated crops in South Africa. WRC Report TT 745/17. Water Research Commission, Pretoria

van Wilgen BW, Scott DF (2001) Managing fires on the Cape Peninsula: dealing with the inevitable. J Mediterr Ecol 2:197-208

van Wilgen BW, Wilson JR (eds) (2018) The status of biological invasions and their management in South Africa in 2017. South African National Biodiversity Institute, Kirstenbosch and DST-NRF Centre of Excellence for Invasion Biology, Stellenbosch

van Wilgen BW, Bond WJ, Richardson DM (1992) Ecosystem management. In: Cowling RM (ed) The ecology of fynbos: nutrients, fire and diversity. Oxford University Press, Cape Town, pp 345-371

van Wilgen BW, Little PR, Chapman RA et al (1997) The sustainable development of water resources: history, financial costs, and benefits of alien plant control programmes. S Afr J Sci 93:404-411

van Wilgen BW, Le Maitre DC, Cowling RM (1998) Ecosystem services, efficiency, sustainability and equity: South Africa's Working for Water Programme. Trends Ecol Evol 13:378. https:// doi.org/10.1016/S0169-5347(98)01434-7

van Wilgen BW, Nel JL, Rouget M (2007) Invasive alien plants and South African rivers: a proposed approach to the prioritization of control operations. Freshw Biol 52:711-723. https://doi.org/10.1111/j.1365-2427.2006.01711.x

van Wilgen BW, Carruthers J, Cowling RM et al (2016) Ecological research and conservation management in the Cape Floristic Region between 1945 and 2015: history, current understanding and future challenges. Trans R Soc South Africa 71:207-303. https://doi.org/10.1080/ 0035919X.2016.1225607

van Wilgen BW, Measey J, Richardson DM, Wilson JR, Zengeya TA (2020) Biological invasions in South Africa-an overview. In: van Wilgen BW, Measey J, Richardson DM, Wilson JR, Zengeya TA (eds) Biological invasions in South Africa. Springer, Heidelberg, pp 3-30. https:// doi.org/10.1007/978-3-030-32394-3_1 
van Wyk DB (1987) Some impacts of afforestation on streamflow in the Western Cape Province, South Africa. Water SA 13:31-36

Versfeld DB, van Wilgen BW (1986) Impacts of woody aliens on ecosystem properties. In: Macdonald IAW, Kruger FJ, Ferrar AA (eds) The ecology and control of biological invasions in South Africa. Oxford University Press, Cape Town, pp 239-246

Vundla T, Blignaut J, Nkambule $\mathrm{N}$ et al (2016) The opportunity cost of not utilising the woody invasive alien plant species in the Kouga, Krom and Baviaans catchments in South Africa. South Afr J Econ Manag Sci 19:774-787. https://doi.org/10.4102/sajems.v19i5.1603

Wicht CL (1949) Forestry and water supplies in South Africa. Bulletin No. 33. Pretoria, Department of Forestry, Union of South Africa

WWF-SA (2013) An introduction to South Africa's water source areas. WWF South Africa, Cape Town

Yapi TS (2013) An assessment of the impacts of invasive Australian wattle species on grazing provision and livestock production in South Africa. M.Sc. Conservation Ecology, Stellenbosch University

Zhang L, Dawes WR, Walker GR (2001) Response of mean annual evapotranspiration to vegetation changes at catchment scale. Water Resour Res 37:701-708. https://doi.org/10.1029/ 2000WR900325

Open Access This chapter is licensed under the terms of the Creative Commons Attribution 4.0 International License (http://creativecommons.org/licenses/by/4.0/), which permits use, sharing, adaptation, distribution and reproduction in any medium or format, as long as you give appropriate credit to the original author(s) and the source, provide a link to the Creative Commons licence and indicate if changes were made.

The images or other third party material in this chapter are included in the chapter's Creative Commons licence, unless indicated otherwise in a credit line to the material. If material is not included in the chapter's Creative Commons licence and your intended use is not permitted by statutory regulation or exceeds the permitted use, you will need to obtain permission directly from the copyright holder. 